\title{
APPLICATION OF QUALITY CONTROL TOOLS IN A BICYCLE INDUSTRY: A CASE STUDY
}

\author{
Deepak $^{1}$, Dheeraj Dhingra ${ }^{2}$ \\ ${ }^{1}$ Lecturer, Mechanical Engineering Department, RIMT Polytechnic College, Punjab, India \\ ${ }^{2}$ Lecturer, Mechanical Engineering Department, RIMT Polytechnic College, Punjab, India
}

\begin{abstract}
Quality plays very important role in today's highly competitive industrial environment. Quality leads to an improvement in the productivity. By improving quality, the method of optimization reduces process operational cost and variations in product. Quality control $(Q C)$ tools are used to solve more than 90 percent of the problems faced by the organizations for improving its effectiveness and meeting or exceeding the customer expectation on a continuous basis. The success of the quality control procedure depends greatly on method of data collection and its accuracy. The Present study is aimed toward reducing the rejection of Bicycle rims by application of Quality Control $(Q C)$ Tools. A case study has been conducted in a bicycle industry in Ludhiana to improve the quality of the bicycle rims. The Quality tools such as Pareto chart, Fishbone diagram have been applied to improve the quality of the products. It has been found that monthly defects were reduced to greater extent. The various process parameters such as heating voltage, temperature of heated water, time of chemical coating processes, chemical composition of the material and quality of heated water etc. which have influence of the quality of final product have to be controlled in order to reduce the wastage and also there has been observed a need of improvement in guide mechanism and storage methods to reduce the problems that results from manufacturing process by using the quality control tools. The rusty boiler tubes and rusty pipelines also need proper cleaning at regular intervals. The Company where the study was carried out is Partap Bikes, Ludhiana.
\end{abstract}

Keywords: 7 Quality Control tool, Cause-effect Diagram, Pareto Diagram, Scrap Reduction,

\section{INTRODUCTION}

Quality improvement is a continuous process which assumes the implementation of quality control tools. Quality is very important in today's competitive environment. It is not only necessary to reduce the wastage, but also to satisfy customer's expectations, continuous cost reductions and continuous improvements to survive in highly competitive environment. In today's competitive economy quality with minimum cost are dependent factors. Quality control tools can be applied in product development, production and marketing also. The quality control is aimed to satisfy the customers by delivery of defect free products. The research is aimed to investigate the successful application of quality control tools in industry. Quality, productivity and cost of operation relatively dependent on each other [4]. The main goal of quality management is customer satisfaction by delivery of defect free products at minimum cost. By application of quality tools cost of Rs.12677.57 saved per year. Jha et al. (2013) conducted a case study to reduce the scrap in automotive assembly lines using quality control tools [16]. It results in huge saving in cost to the company. The study conducted by Fouad and Mukattash (2010) in steel industry helps to reduce majority of problems related to the quality[5]. In this research, the rejection of bicycle Rims has been reduced by application of quality control tools in Bicycle Rim manufacturing industry located in Ludhiana. The study will be highly beneficial for bicycle industry.

\subsection{Benefits of Quality Control Tool}

- Helps in controlling the rejection and rework.

- Helps in customer satisfaction by reduction in customer complaints.

- Beneficial for reducing the production cost.

- Improvement in the process.

- Helps in finding the root causes of problem.

\subsection{Quality Control tools}

Quality Control tools are statistical tools for solving the quality related problems. The following are the quality control tools used to solve problems.

\subsubsection{Check Sheet}

Check sheet is a table created by tallying each type of defect for a specified time. It shows the defects and how many time each type of defect occurred during that period. On the basis of information obtained the improvement actions can be taken.

\subsubsection{Pareto Chart}

Pareto chart is frequency distribution of attribute data arranged by category. These are extremely useful to find the factors which have greatest effect on system and allow the users to focus attention on these factors and screen out the less significant factors. 


\subsubsection{Flow Chart}

Flow charts are pictorial representation of process by breaking the process down into its constituent steps. Flowcharts are helpful in identifying where errors are likely to found in the system. In quality improvement process flowcharts are particularly useful for displaying how a process currently functions or could ideally function.

\subsubsection{Cause and Effect Diagram}

The cause and effect diagram is used to associate multiple possible causes with a single effect. Causes in cause and effect diagram are frequently arranged into four major's categories. These categories can be anything: Manpower, Methods, Materials and Machinery.

\subsubsection{Histogram}

Histogram is a special bar chart for measurement data. It is used to chart the frequency of occurrences.

\subsubsection{Scatter Diagram}

Scatter diagram graphical representation to determine correlation between two variables. The shape of scatter diagram indicates the relationship between two variables.

\subsubsection{Control Chart}

The control chart is a fundamental tool of statistical process control as it indicates the range of variability that is built into a system. Thus it helps to determine whether or not a process is operating consistently or if special cause has occurred to change process mean or variance.

\section{LITERATURE REVIEW}

The Continuous process improvement requires appropriate quality control tools and is of matter of facts collected with precisions. [3] implemented the QC tools in Cement Industry to control the quality of ready mix cement. [5]proposed key ingredient for successful quality management by application of statistical process control and seven basic quality control tools. [9] implemented two Quality Control (Pareto analysis and Cause \& effect diagram) tools to reduce the rejection of casting components in an automobile industry. This study results in reduce from $10 \%$ to $8.23 \%$ and saving of Rs. 27.7 Lakhs per year. [18] planned a study to reduce the rejection of castings using Quality control tools (QC) in North India. The study results in annual saving of Rs. 10 lakhs. [14] conducted a study aimed to find out the causes of quality related problems. Quality tools like cause and effect diagram, histogram, Pareto diagram and check sheet were used in the study. The major causes of rejection i.e. seal ring pore, latex coating damage and mating ring chip were controlled by appropriate action and defects were reduced from $9.6 \%$ to $7.9 \%$.

\section{RESEARCH METHODOLOGY}

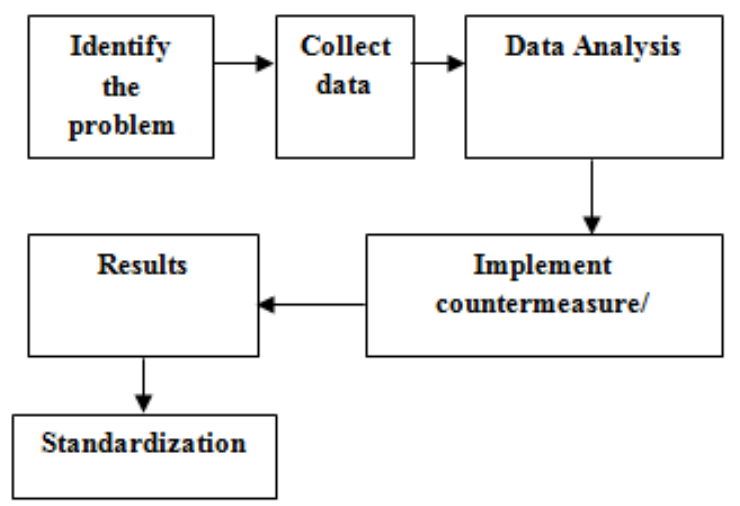

Fig -1: Research methodology

\subsection{Identify the Problem}

Defects in rim manufacturing includes corrosion in storage conditions, scratches/ marks, incorrect hole alignment, dents, weld gaps, rim explosion, incorrect cross section geometry, non-circularity in shape which were observed. This leads to high monthly rejection.

\subsection{Data Collection}

The rejection data has been collected from the industry using daily inspection reports and rearrange the data defect wise.

\subsection{Data Analysis}

Two Quality tools namely Pareto chart and Fishbone diagram has been used for data analysis in the study.

\subsection{Corrective Actions}

To reduce the rejection of rims corrective and preventive actions were taken.

\subsection{Results}

On the basis of outcome of previous steps results, conclusions were taken regarding key issues.

\subsection{Standardization}

Standard operating procedures were revised after analysis the results.

\section{PROBLEM FORMULATION}

There are many quality related problems which were observed during the work in industry. The Rejection observed was $9.45 \%$ which was alarming due to some critical manufacturing defects. The temperature of water for coating the chromium is $\left(55^{\circ} \mathrm{C}-60^{\circ} \mathrm{C}\right)$ but the actual coating temperature was below the specified range. Raw material was also rusty. The time of chromium plating ( 5 minutes) was less them actual time (8-10 minutes) required for ensuring the effectiveness of coating. Boiler tubes also to be cleaned for ensuring the proper heat transfer to water to raise the water to desired temperature without overheating 
the tubes of the boilers. Unskilled handling of components leads to non-circular shape of rim. Material should also be cleaned and rust free before butt welding to ensure a sound welded joint. Misaligned welded joint was also a problem in manufacturing. Due to all these reasons there are many defects in rim which includes corrosion in storage conditions, scratches/ marks, incorrect hole alignment, dents, weld gaps, weld breakage, incorrect cross section geometry, non-circularity in shape.

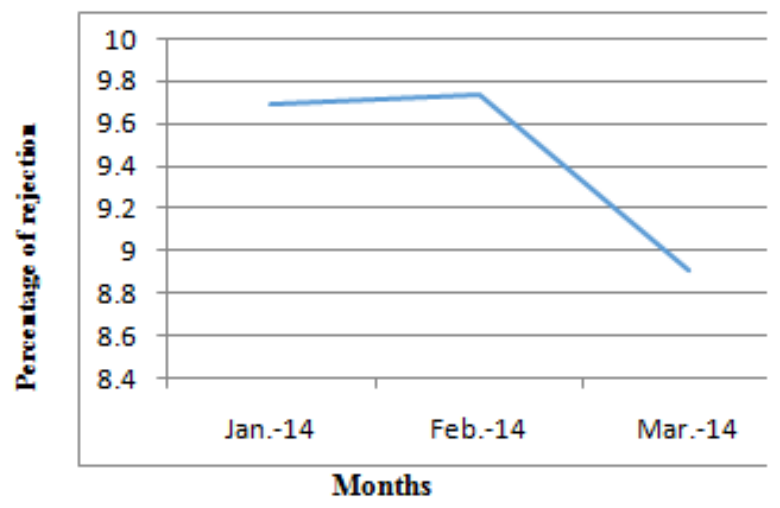

Chart -1: Rejection Trend of ISO Rims

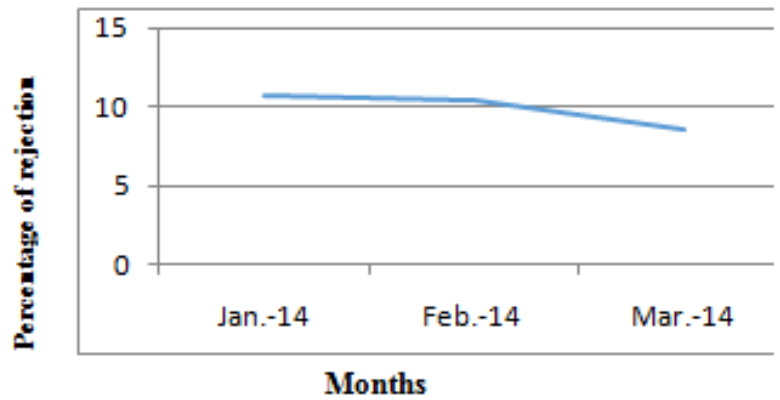

Chart -2: Rejection trend of ISO 26"Rim

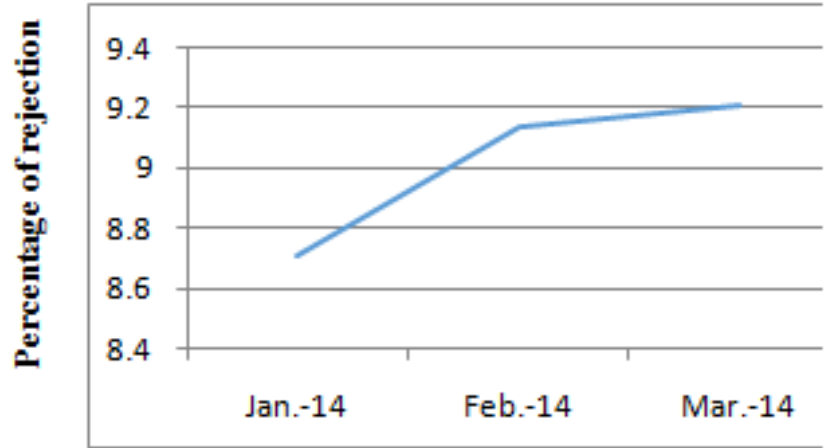

Months

Chart -3: Rejection trend of ISO 28"Rim

Chart No 2 and Chart No.3show the rejection trend ISO 26" \& ISO 28"rims. The rejection trend is different for both of rims due to different sizes. Figure 3.3 shows the Pareto analysis of the Rims. First five defects contribute more than $80 \%$ of rejection. Corrosion contributes $35 \%$ of total. Cumulative percentages are also given in the table. The defects were arranged in descending order so as to focus more on few important factors and less on least significant defects with least contribution to the total defects.

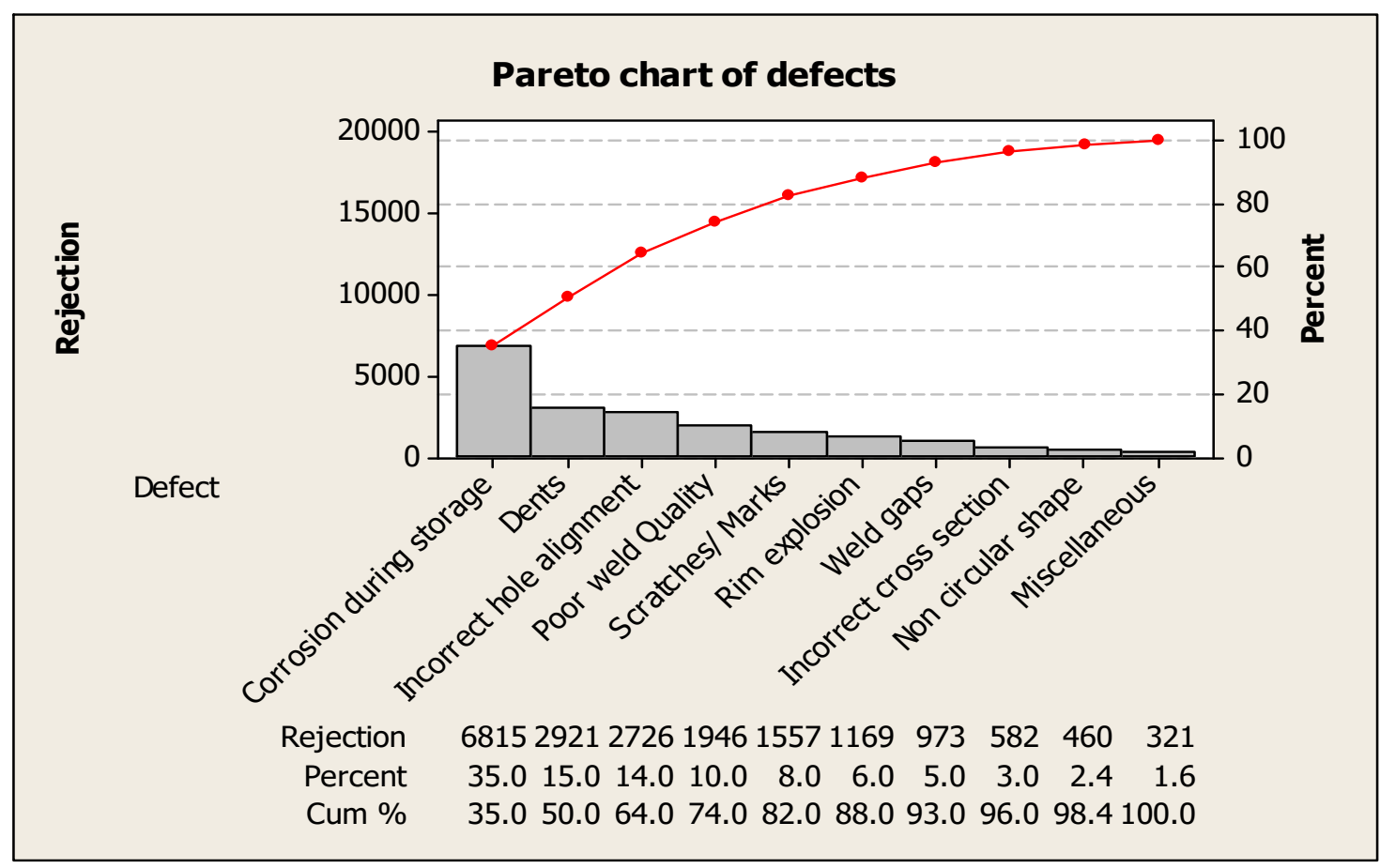

Fig -2: Pareto Chart of Rim Defects 
Table -1: Rim defects

\begin{tabular}{|l|l|l|l|l|}
\hline S.No & $\begin{array}{l}\text { Name of } \\
\text { defect }\end{array}$ & Rejection & $\begin{array}{l}\text { Cumulative } \\
\text { Rejection }\end{array}$ & $\begin{array}{l}\text { Cumulative } \\
\%\end{array}$ \\
\hline A & Corrosion & 6815 & 6815 & 35.01 \\
\hline B & Dents & 2921 & 9736 & 50.01 \\
\hline C & $\begin{array}{l}\text { Incorrect hole } \\
\text { alignment }\end{array}$ & 2726 & 12462 & 64.01 \\
\hline D & $\begin{array}{l}\text { Poor weld } \\
\text { Quality }\end{array}$ & 1946 & 14408 & 74.02 \\
\hline E & $\begin{array}{l}\text { Scratches/ } \\
\text { Marks }\end{array}$ & 1557 & 15965 & 81.99 \\
\hline F & Rim explosion & 1169 & 17134 & 88.02 \\
\hline G & Weld Gaps & 973 & 18107 & 92.99 \\
\hline H & $\begin{array}{l}\text { Incorrect cross } \\
\text { section }\end{array}$ & 582 & 18669 & 95.88 \\
\hline I & $\begin{array}{l}\text { Non circular } \\
\text { shape }\end{array}$ & 460 & 19149 & 98.35 \\
\hline J & Miscellaneous & 321 & 19470 & 100 \\
\hline
\end{tabular}

\section{RESULTS AND DISCUSSIONS}

\subsection{Corrosion of Rim}

\section{MAN METHOD}

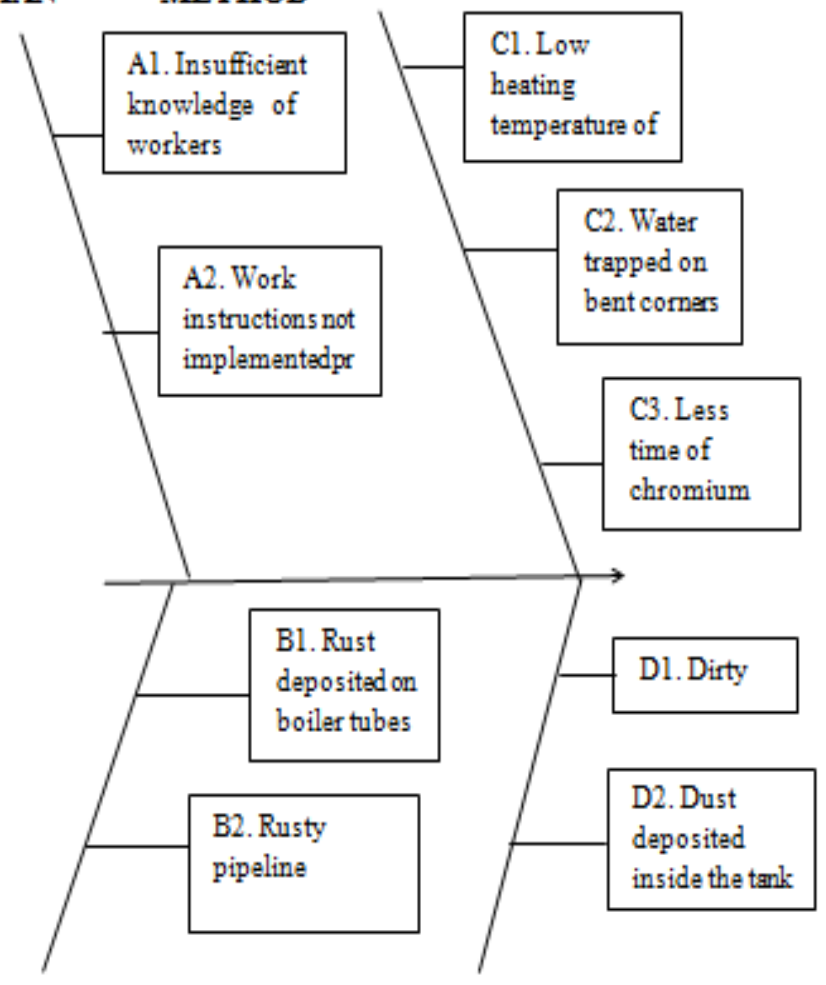

MACHINES

MATERIAL

Fig -3: Fishbone diagram for Corrosion of rim
Table -2: Counter Measures for corrosion of rims

\begin{tabular}{|l|l|}
\hline S. No & Counter Measure for Man \\
\hline A1 & $\begin{array}{l}\text { Sufficient knowledge given to operators about the } \\
\text { method of chromium dipping. }\end{array}$ \\
\hline $\mathbf{A 2}$ & Specific work instructions provided to the workers \\
\hline
\end{tabular}
regarding the causes of corrosion defect.

(i) Check the cleanliness of rims before dipping, if found unclean then separate and report to quality persons.

(ii) Not to insert more than 50 rims at a time.

(iii) Temperature of water should be checked after every 2 hours.

(iv) Clean the boiler tubes and pipelines after three months.

\begin{tabular}{|l|l|}
\hline & Counter Measures for Method \\
\hline B1 & It has been found that the heating of water is done \\
\hline
\end{tabular}

at range of $40^{\circ} \mathrm{C}-45^{\circ} \mathrm{C}$ which is low. The heating temperature increased in the range of $55^{\circ} \mathrm{C}-60^{\circ} \mathrm{C}$ to have proper chemical reaction of chromium to increase the corrosion resistance.

B2 $\quad$ To have escaping of water trapped on side bent corners Provide two holes on the bent corner opposite to each other for escaping and reducing the tendency of corrosion on sides.

B3 $\quad$ The actual time of chromium dipping process observed was 5 minutes very less then the actual time. So it was suggested to Set the dipping time in range 8 minutes-10 minutes.

\begin{tabular}{|l|l|}
\hline C1 & Counter Measures for Machines \\
\hline It was observes that the boiler tubes were rusty due
\end{tabular} to which the rate of heat transfer reduces and also efficiency of boiler reduces by $10 \%$ and even with having the proper fuel supply the required temperature (55-60 degree) was not reached. So after careful inspection the boiler tubes were cleaned.

C2 $\quad$ The pipeline also found rusty which was cleaned.

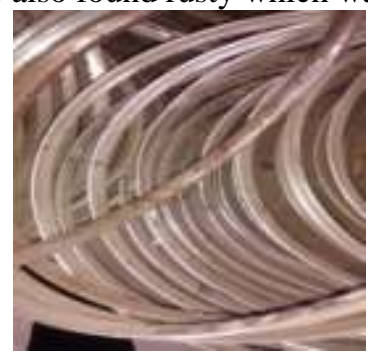

Fig -4:Rusty rims

\begin{tabular}{|l|l|}
\hline & Counter Measures for Material \\
\hline D1 & $\begin{array}{l}\text { Check the cleanliness of water before mixing in the } \\
\text { tank. }\end{array}$ \\
\hline D2 & $\begin{array}{l}\text { Before starting the chromium coating process tank } \\
\text { should also be cleaned properly. }\end{array}$ \\
\hline
\end{tabular}




\subsection{Dents}

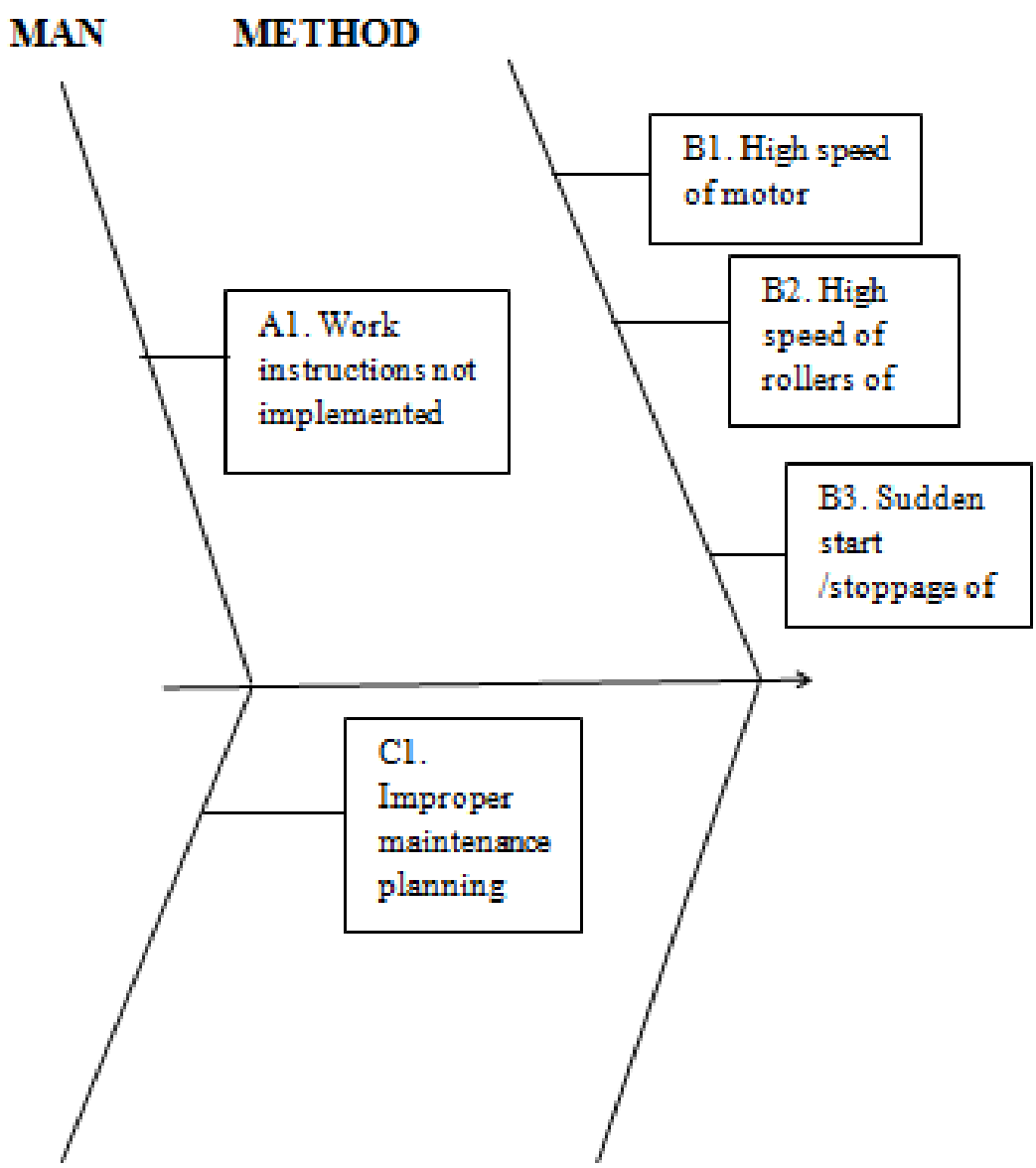

MACHINES MATERIAL

Fig-5: Fishbone Diagram for Dents

Table -3: Counter Measures for Dents

\begin{tabular}{|c|c|}
\hline S. No & Counter Measure for Man \\
\hline A1 & $\begin{array}{l}\text { Specific work instructions provided to the workers regarding the causes of Dents. } \\
\text { (i) Handle the rims carefully and avoid hitting with each other. } \\
\text { (ii) Hand gloves should be used to have proper grip of hands while handling the rims }\end{array}$ \\
\hline & Counter Measures for Method \\
\hline B1 & Speed of motor should be increased from starting to operational (1440) r. p.m. in 2 minutes. \\
\hline B2 & Speed of rollers not to exceed 10 r.p.m \\
\hline \multirow[t]{2}{*}{ B3 } & $\begin{array}{l}\text { Allow rollers to run freely for } 1 \text { minute and then increase the speed slowly and also allow one minute for reducing the } \\
\text { speed and then stopping the machine in order to reduce the shocks which can cause dents on rims. }\end{array}$ \\
\hline & Counter Measures for Machines \\
\hline C1 & $\begin{array}{l}\text { Maintenance of rolling machines should be done once in three months to avoid breakdown especially in the running } \\
\text { conditions. }\end{array}$ \\
\hline
\end{tabular}


Table -4: Details of rejection of ISO 26" Rims

\begin{tabular}{|c|c|c|c|c|c|c|c|c|c|}
\hline & Jan-14 & Feb-14 & $\begin{array}{l}\text { Mar- } \\
14\end{array}$ & $\begin{array}{l}\text { Apr- } \\
14\end{array}$ & $\begin{array}{l}\text { May- } \\
14\end{array}$ & Jun-14 & $\begin{array}{l}\text { Rejection } \\
\% \\
\text { (Jan-Mar) }\end{array}$ & $\begin{array}{l}\text { Rejection } \\
\% \\
\text { (Apr-Jun) }\end{array}$ & $\begin{array}{l}\text { Net } \\
\text { Reduction }\end{array}$ \\
\hline Monthly Rejection & 9.69 & 9.74 & 8.90 & 7.88 & 7.87 & 7.50 & & & \\
\hline Item & $\begin{array}{l}\text { ISO } \\
26 "\end{array}$ & $\begin{array}{l}\text { ISO } \\
26 "\end{array}$ & $\begin{array}{l}\text { ISO } \\
26 "\end{array}$ & $\begin{array}{l}\text { ISO } \\
26 "\end{array}$ & $\begin{array}{l}\text { ISO } \\
\text { 26" }\end{array}$ & $\begin{array}{l}\text { ISO } \\
\text { 26" }\end{array}$ & & & \\
\hline$\%$ age Rejection & 10.64 & 10.33 & 8.60 & 7.97 & 7.93 & 7.36 & & & \\
\hline OK & 30481 & 31985 & 32723 & 35711 & 35099 & 30116 & & & \\
\hline Not OK & 3633 & 3686 & 3079 & 3093 & 3025 & 2396 & & & \\
\hline Rej. Pts. & & & & & & & & & \\
\hline Corrosion & 1205 & 1309 & 1229 & 1098 & 1036 & 901 & 3.54 & 2.77 & 0.77 \\
\hline Dents & 623 & 521 & 416 & 520 & 496 & 344 & 1.47 & 1.24 & 0.23 \\
\hline $\begin{array}{l}\text { Incorrect } \\
\text { alignment }\end{array}$ & 459 & 583 & 414 & 452 & 425 & 313 & 1.37 & 1.08 & 0.29 \\
\hline Poor Weld quality & 420 & 308 & 311 & 354 & 285 & 211 & 0.98 & 0.77 & 0.21 \\
\hline Scratches/ Marks & 311 & 255 & 269 & 203 & 283 & 197 & 0.89 & 0.62 & 0.27 \\
\hline Rim Explosions & 159 & 295 & 159 & 173 & 185 & 153 & 0.57 & 0.47 & 0.10 \\
\hline Weld Gaps & 205 & 198 & 121 & 143 & 152 & 125 & 0.50 & 0.38 & 0.12 \\
\hline $\begin{array}{ll}\text { Incorrect } & \text { Cross } \\
\text { Section } & \end{array}$ & 138 & 120 & 67 & 86 & 93 & 71 & 0.31 & 0.23 & 0.08 \\
\hline $\begin{array}{ll}\text { Non } & \text { Circular } \\
\text { Shape } & \end{array}$ & 68 & 71 & 41 & 39 & 48 & 38 & 0.17 & 0.11 & 0.06 \\
\hline Miscellaneous & 45 & 26 & 52 & 25 & 22 & 43 & 0.12 & 0.08 & 0.04 \\
\hline $\begin{array}{l}\text { Total piece (Jan- } \\
\text { Mar) }\end{array}$ & 105587 & & & & & & & & \\
\hline Reject (Jan-Mar) & 10398 & & & & & & & & \\
\hline $\begin{array}{l}\text { Rejection (Jan- } \\
\text { Mar)\% }\end{array}$ & 9.84 & & & & & & & & \\
\hline $\begin{array}{l}\text { Total piece (Apr- } \\
\text { Jun) }\end{array}$ & 109440 & & \multicolumn{7}{|c|}{ Reduction in Rejection $=9.84-7.77=2.07=176$ pieces per month } \\
\hline Reject (Apr-Jun) & 8514 & & \multicolumn{7}{|c|}{ Cost of one piece $=$ Rs.102 } \\
\hline $\begin{array}{l}\text { Rejection } \\
\text { Jun)\% }\end{array}$ & 7.77 & & \multicolumn{7}{|c|}{ Saving in one month $=176 \times 102=17952$} \\
\hline & & & \multicolumn{7}{|c|}{ Saving in one year $=17952 \times 12=215424$} \\
\hline
\end{tabular}

Table -5: Details of rejection of ISO 28" Rims

\begin{tabular}{|c|c|c|c|c|c|c|c|c|c|}
\hline & Jan-14 & $\begin{array}{l}\text { Feb- } \\
14\end{array}$ & $\begin{array}{l}\text { Mar- } \\
14\end{array}$ & $\begin{array}{l}\text { Apr- } \\
14\end{array}$ & $\begin{array}{l}\text { May- } \\
14\end{array}$ & Jun-14 & $\begin{array}{l}\text { Rejection } \% \\
\text { (Jan-Mar) }\end{array}$ & $\begin{array}{l}\text { Rejection } \\
\% \\
\text { (Apr-Jun) }\end{array}$ & $\begin{array}{l}\text { Net } \\
\text { Reduction }\end{array}$ \\
\hline Monthly Rejection & 9.69 & 9.74 & 8.90 & 7.88 & 7.87 & 7.50 & & & \\
\hline Item & $\begin{array}{l}\text { ISO } \\
28 "\end{array}$ & $\begin{array}{l}\text { ISO } \\
28 ”\end{array}$ & $\begin{array}{l}\text { ISO } \\
28 ”\end{array}$ & $\begin{array}{l}\text { ISO } \\
28 ”\end{array}$ & $\begin{array}{l}\text { ISO } \\
28 "\end{array}$ & $\begin{array}{l}\text { ISO } \\
28 ”\end{array}$ & & & \\
\hline$\%$ age Rejection & 8.71 & 9.14 & 9.21 & 7.75 & 7.80 & 7.61 & & & \\
\hline OK & 30157 & 31977 & 29279 & 32020 & 32299 & 32700 & & & \\
\hline Not OK & 2880 & 3220 & 2972 & 2690 & 2734 & 2695 & & & \\
\hline \multicolumn{10}{|l|}{ Rej. Pts. } \\
\hline Corrosion & 962 & 1024 & 935 & 853 & 897 & 862 & 2.90 & 2.48 & 0.42 \\
\hline Dents & 419 & 452 & 437 & 387 & 392 & 365 & 1.30 & 1.08 & 0.22 \\
\hline $\begin{array}{l}\text { Incorrect } \quad \text { Hole } \\
\text { alignment }\end{array}$ & 322 & 298 & 325 & 295 & 279 & 320 & 0.94 & 0.85 & 0.09 \\
\hline Poor Weld quality & 296 & 280 & 258 & 228 & 192 & 195 & 0.80 & 0.58 & 0.22 \\
\hline Scratches/ Marks & 259 & 269 & 236 & 222 & 211 & 215 & 0.76 & 0.62 & 0.14 \\
\hline Rim Explosions & 213 & 240 & 219 & 197 & 193 & 198 & 0.66 & 0.55 & 0.11 \\
\hline Weld Gaps & 174 & 215 & 227 & 202 & 184 & 200 & 0.61 & 0.56 & 0.05 \\
\hline $\begin{array}{ll}\text { Incorrect } & \text { Cross } \\
\text { Section } & \\
\end{array}$ & 102 & 198 & 174 & 115 & 124 & 132 & 0.47 & 0.35 & 0.12 \\
\hline Non $\quad$ Circular & 81 & 142 & 58 & 64 & 117 & 69 & 0.27 & 0.23 & 0.03 \\
\hline
\end{tabular}




\begin{tabular}{|l|l|l|l|l|l|l|l|l|l|}
\hline Shape & & & & & & & & \\
\hline Miscellaneous & 52 & 112 & 103 & 127 & 145 & 139 & 0.26 & 0.39 & -0.13 \\
\hline $\begin{array}{l}\text { Total piece (Jan- } \\
\text { Mar) }\end{array}$ & 100485 & & & & & & & & \\
\hline Reject (Jan-Mar) & 9062 & & & & & & & & \\
\hline $\begin{array}{l}\text { Rejection (Jan- } \\
\text { Mar)\% }\end{array}$ & 9.02 & & & & & & & & \\
\hline $\begin{array}{l}\text { Total piece (Apr- } \\
\text { Jun) }\end{array}$ & 105138 & & & & & & & \\
\hline Reject (Apr-Jun) & 8119 & & & & & \\
\hline $\begin{array}{l}\text { Rejection (Apr- } \\
\text { Jun)\% }\end{array}$ & 7.72 & \multicolumn{7}{|l|}{ Sast of one piece = Rs.110 } \\
\hline
\end{tabular}

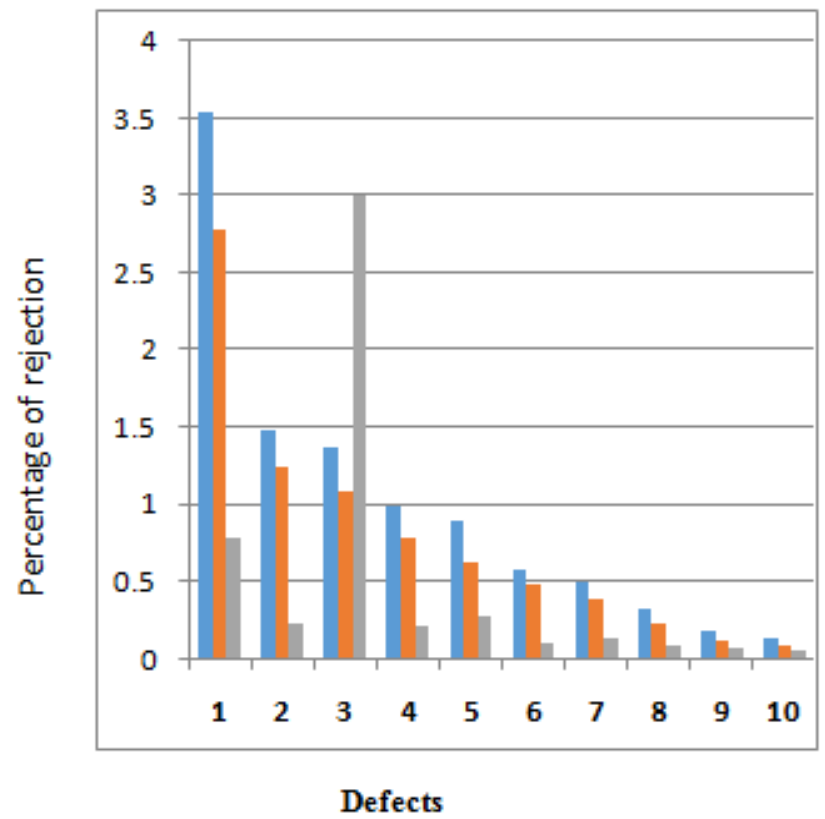

Chart -4: Rejection of ISO 26"Rims

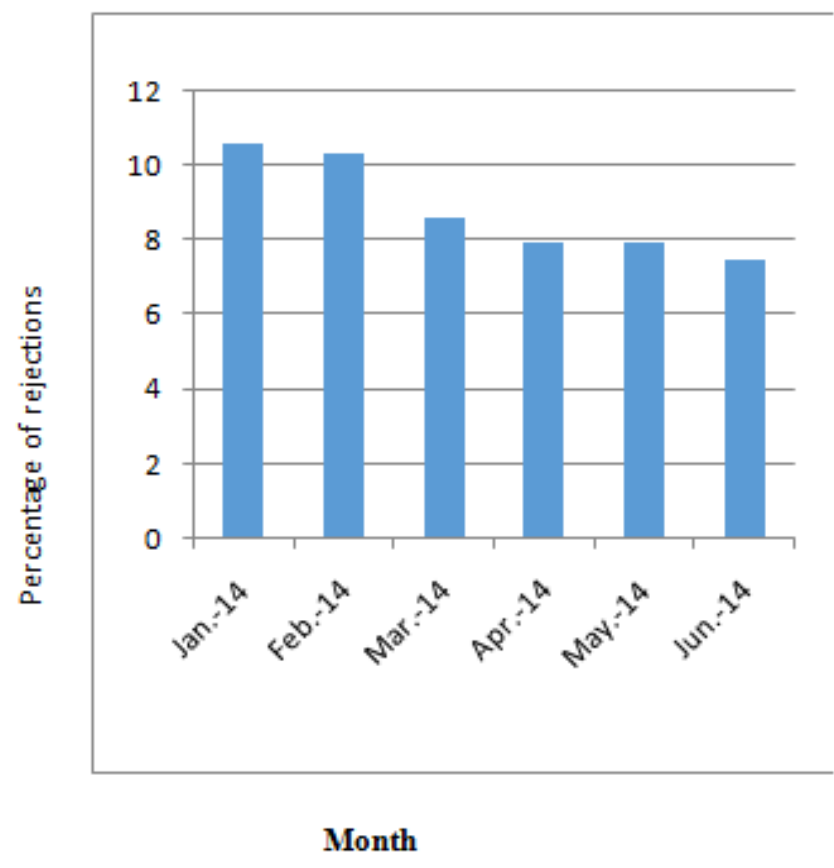

Chart -5: Monthly rejection of ISO 26" Rims

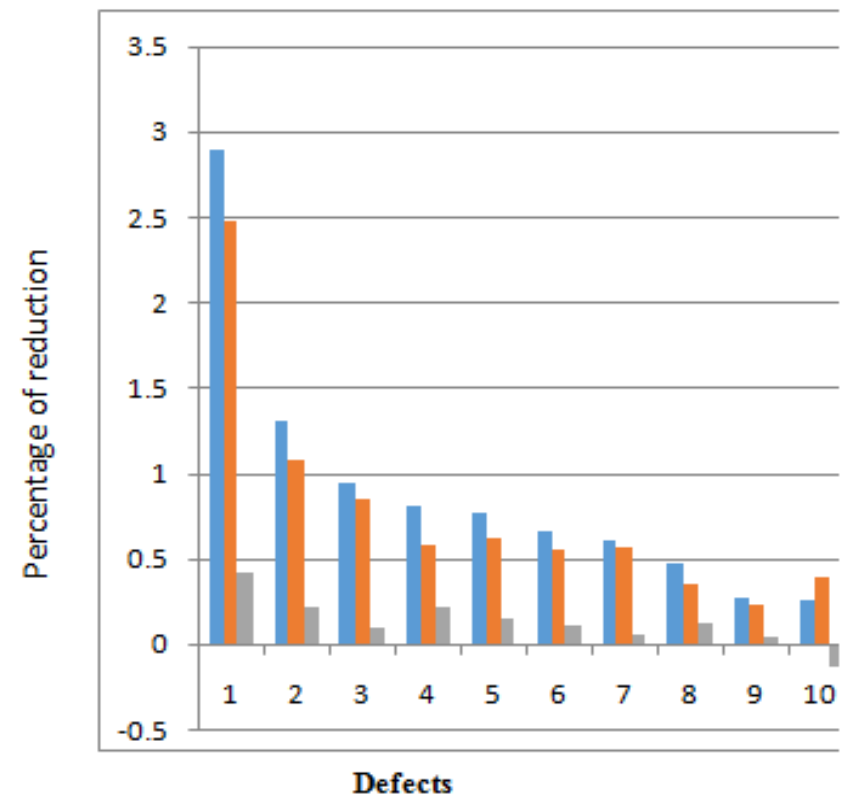

Chart -6: Rejection of ISO 28" Rims

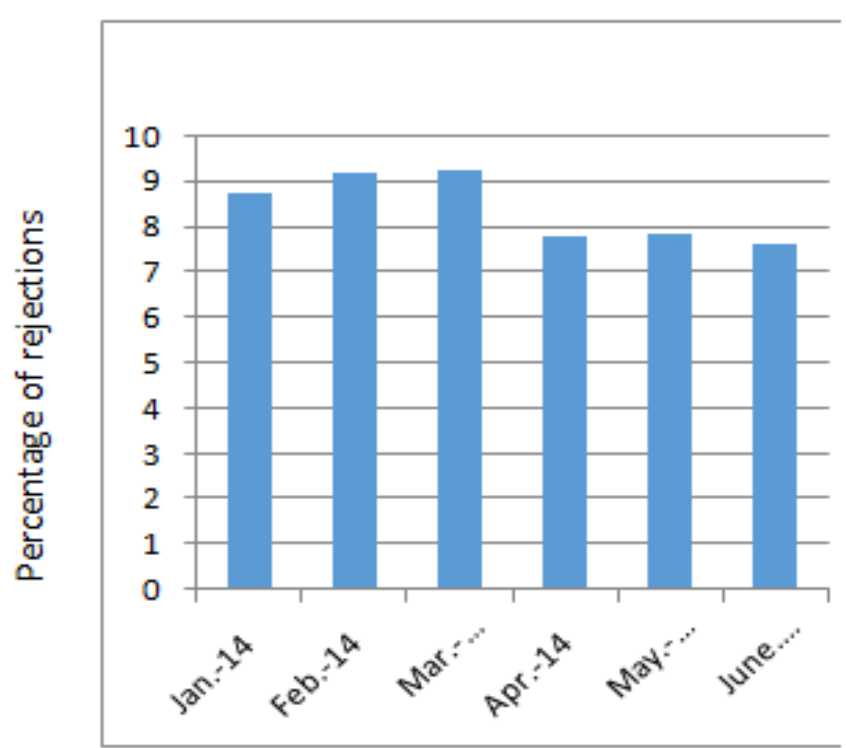




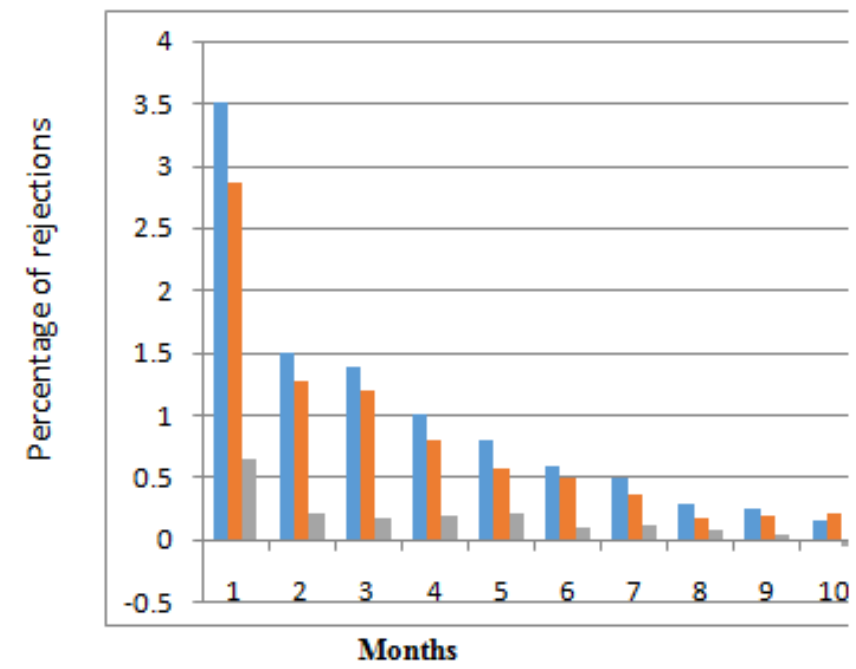

Chart -8: Overall Rejection of Rims

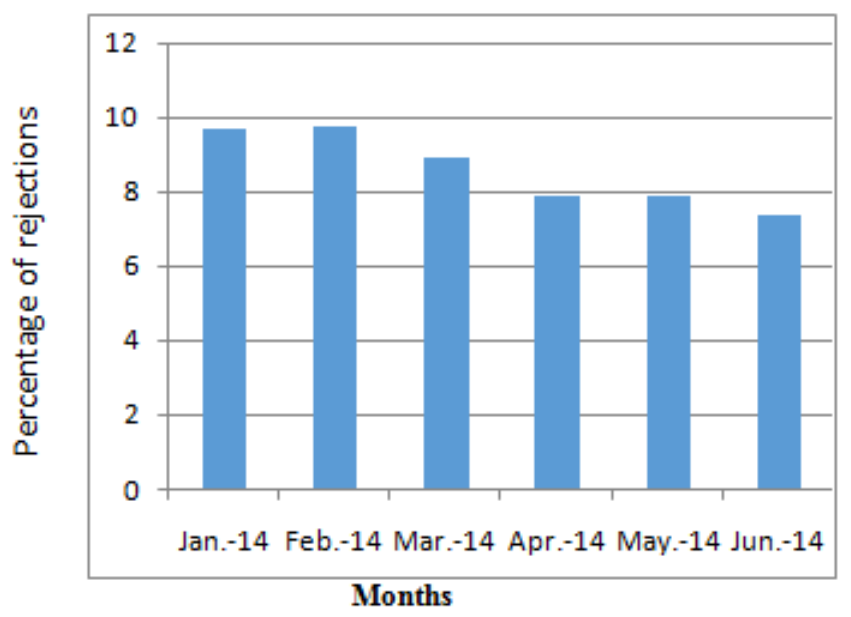

Chart -9: Overall Monthly rejections of Rims

\section{CONCLUSION}

Quality leads to improvement in productivity and at the same time it also leads to customer's satisfaction. Study has been conducted to define the role of quality control tools in Bicycle rim manufacturing industry. In the Quality management system these tools can be much wider applied with certain success. Quality tools are not so wider spread as expected although they are quite simple for application an easy for interpretations. Main goal of the study is to reduce the cost per component by reduction in monthly rejection of the components After studying the problems, various parameters affecting the quality of the final product were identified and data was collected with accuracy and precision and some standard working procedure were proposed for chemical coating, stacking and material handling and remedies were also proposed. Quality tools i.e. Pareto chart, Cause and Effect Diagram were used in the study. The main conclusions of the study are summarized as below.

- Rejection of the rims has been reduced from $9.45 \%$ to $7.75 \%$ for overall production of the components.

- Saving of Rs. 3.54 lakhs per year.

- Material handling and stacking process are also standardized.
- By proper regular cleaning of boiler tubes the higher efficiency can be obtained and saving in fuel (up to $10 \%$ ) can be achieved.

\section{REFERENCES}

[1]. Kumar S, Mantha S.S. and Kumar A(2003),"Scrap reduction by using total quality management tools," International Journal of industrial Engineering, Vol. 16, No. 4, pp. 364-369

[2]. Pavietic D, Socovic M and Paliska G (2008)," Practical Application of Quality Tools," International journal of quality research, Vol. 3, No.3, pp. 297-305.

[3]. Paliska G, Pavletic D and Sokovic M (2008), “Application of Quality Engineering tools in process industry," Advanced Engineering Journal,Vol.2, No.1, pp. 73-86

[4]. Mandavgade N.K. and JajuS.B. (2009),'Optimization of Cost by Using 7 QC tools," International Journal of Engineering Studies, Vol.1, No.3, pp. 149-160

[5]. Fouad H.K., Mukattash A (2010),'Statistical Process Control: A Practical guide for Jordanian Industrial Organization's, “Jordan Journal of Mechanical and Industrial Engineering, Vol. 4, No. 6, pp. 693-700.

[6]. Matathil A, Ganapathi K.N. and RamachandranK (2012),"Reduction of Scrap in an Electronic Assembly Line using DMAIC Approach," SASTECH Journal, Vol. 11, No. 2, pp. 53-59.

[7]. Islam M, Khan M and Khan R (2012)," Minimization of reworks in quality and productivity improvement in the apparel industry," International Journal of Engineering and Applied Science, Vol. 1, No. 2, pp.147-164.

[8]. Sarao S.M, Srinivas B, Thampi G.T. Patil B.T and Dalvi D.S (2012)," Enhancing Waste Reduction through Lean Manufacturing Tools and Techniques," International Journal of Research in Management and Technology,Vol. 2, No. 2, pp. 253-257.

[9]. Pal J (2012)," Implementation of Quality Control Tools in an Automobile Organization to Reduce the rejection of Casting Components," International Conference on Research and Innovations in Mechanical Engineering, pp. 613-622.

[10]. Solanki S and Bangar A(2013),"Analysis for Reduction in Process rejection of Plastic Molding Jar By Using Six Sigma Methodology," International Journal of Engineering Science and Technology, Vol. 5, No. 11, pp. 1824-1831.

[11]. Hekmatpanah M, Ravichandra N, Shahin A and Ahmadi H(2013)," Investigating the Application of Six Sigma methodology and Quality Control Tools and Techniques in Sepanhan Oil Company," THE GLOBAL eLearning Journal, Vol. 2, No. 3, pp. 67-74.

[12]. Prajapati D.R. and Cheema D.V. (2013)," Optimization of Weld Crack Explosion Defects of Wheel Rims," International Journal of Innovative Research in Science," Vol. 2, No. 8, pp.3437-3446. 
[13]. Prajapati D.R. (2013), "Implementation of SPC Techniques in Automotive Industry : A Case Study," International Journal of Emerging Technology and Advanced engineering, Vol. 2, No.3, pp.227-241.

[14]. Bhosale D.S, Shilwant S.C. and Patil S.R. (2013)," Quality improvement in manufacturing processes using SQC tools," International Journal of Engineering Research,Vol. 3, No.3, pp. 832-837.

[15]. Surange V.G., Teli S.N., Adak D.D. and Rane S.S. (2013)," Effective Utilization of Quality Cost Reducing Tools in Automobile Industry," International Journal of Advanced Technology and Engineering Research," Vol. 2, No.2, pp. 44-53.

[16]. Jha M, Tyagi R.K., Gupta G (2013),"Reduction of rejected components in an automobile assembly line using quality tools," European Journal of Applied Engineering and Scientific Research and Technology, Vol. 2, No. 3, pp. 1317.

[17]. Patel P.J., Shah S.C. and Makhwana S (2014)," Application of Quality Engineering Tools in Taper shank Drills Manufacturing Industry, "International Journal of Engineering Research and Applications, Vol. 4, No. 2, pp. 129-134.

[18]. Kumar A (2014)," Quantitative Study on the Barriers of Lean Manufacturing Implementation: An Indian Context," The International Journal of Engineering and Science, Vol.3, No.4, pp. 21-28.

[19]. Saleem M, Khan N, Hameed S and Abbas M (2012),"An analysis of relationship between Total Quality Management and Kaizen," Life science Journal, Vol. 9, No. 3, pp. 31-40.

[20]. Rajalingam S, Bono A and Sulaiman J (2012)," Identifying the critical molding machine Parameters affecting injection molding process by Basic Statistical Process control Tools," International Journal of Engineering Science and Technology, Vol. 6, No.3, pp. 358-364.

[21]. Behnam B and Alveos H (2011), "Exploring the potential of Quality Tools in Tire Retreading Industry," International Journal of Engineering Science and Technology, Vol. 3, No. 6, pp. 5337-5345.

[22]. MidorK(2011),"Quality control tools functioning in integrated management system in the automotive branch company "'Scientific Journals, Vol. 27, No. 99, pp. 92-97.

[23]. Teeravargprug J, Kitiwanwong $\mathrm{K}$ and Seatong N (2011)," Relationship model and supporting Activities of JIT, TQM and TPM," Songlanakarim Journal of Engineering Science and Technology, Vol. 33, No. 1, pp. 101-106.

[24]. Judi H, Jenal R and Genasans D (2009),"Some experiences of Quality Control Implementation in Malaysian Companies,". European Journal of Scientific Research, Vol. 27, No. 1, pp. 34-45.

[25]. Putri, Nilda and Yusuf S.M. (2009),'Critical Success factors for Implementing Quality Engineering Tools and Techniques in Malaysian and Indonesian's Automotive Industries, "The international Multiconference of Engineers and Computer Scientist,” Vol. 2, pp. 978-988.

\section{BIOGRAPHIES}

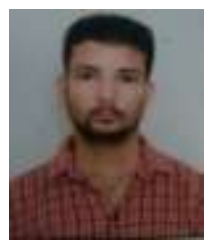

Deepak received his B.Tech Degree in Mechanical Engineering from RIMT-IET, Mandi-Gobingarh, Punjab and M.Tech Degree in Mechanical Engineering from University College of Engineering, Punjabi University, Patiala(Punjab). He is currently working as a Lecturer in Mechanical Engineering Department in RIMT Polytechnic College, MandiGobindgarh, Punjab. His main interests are Quality Control (QC) Tools, Six Sigma, Scrap Reduction and TQM.

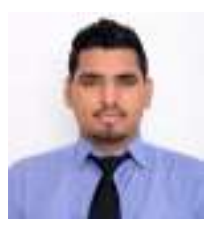

Dheeraj Dhingra obtained B.Tech Degree in Mechanical Engineering from Surya School of Engineering \& Technology, Punjab and currently pursuing M.Tech degree in Production Engineering from RIMT-IET, Mandi-Gobindgarh, Punjab. He is currently working as a Lecturer in RIMT Polytechnic college, Mandi-Gobindgarh, Punjab. Furthermore, he has also done the Six sigma green belt certified course. His main research interests are Six Sigma, DMAIC, TQM, Scrap Reduction, Surface Roughness, Quality Tools, ANOVA and Taguchi method. 